\title{
Floristic composition in deciduous tropical forest to west of Irapuato, Guanajuato
}

\section{Composición florística del Bosque tropical caducifolio al oeste de Irapuato, Guanajuato}

\author{
HERNÁNDEZ-HERNÁNDEZ, Victoria†*, RAMOS-LÓPEZ, Luis Fernando and COLLI-MULL, Juan \\ Gualberto
}

Departamento de Biología, Instituto Tecnológico Superior de Irapuato, carretera Irapuato-Silao km 12.5, 36821 Irapuato, Guanajuato, México

ID $1^{\text {st }}$ Author: Victoria, Hernández-Hernández / ORC ID: 0000-0001-7952 041X

ID $1^{\text {st }}$ Coauthor: Luis Fernando, Ramos-López / ORC ID: 0000-0002-5814 6593

ID $2^{\text {nd }}$ Coauthor: Juan Gualberto, Colli-Mull / ORC ID: 0000-0001-9398 5977

DOI: $10.35429 / J E S N .2019 .15 .5 .36 .43$

Received April 26, 2019; Accepted June 30, 2019

\begin{abstract}
The flora of Irapuato has been poorly explored, because it is an area dedicated to agriculture and there are few strains of tropical deciduous forest and subtropical scrubland. The objectives of the study were to know the floristic composition in Cerro del Veinte, compare the richness of species with other locations that have the same type of vegetation and determine the conservation status of the species according to NOM-059 SEMARNAT-2010. The sampling was through free transects of approximately $1 \mathrm{~km}$ in the Barrancas La Escondida and El Paiste. A total of 59 families, 137 genera, 171 species and four varieties were obtained. The best represented families are Asteraceae, Fabaceae and Pteridaceae. According to the Chao 2 estimator, the sampling effort in the study area was $87 \%$. Floristic affinity in Cerro del Veinte was greater with the Hoya de Rincón de Parangueo (38\%) and Sierra de Pénjamo (32\%). In addition, there are three new species reported for Guanajuato, Govenia lagenophora and Sacoila lanceolata (Orchidaceae) and Solanum edmundoi (Solanaceae). The taxa Cedrela odorata and Erythrina coralloides are included in NOM-059-SEMARNAT2010.
\end{abstract}

Cerro del Veinte, Chao 2 estimator, Orchidaceae

\section{Resumen}

La flora de Irapuato ha sido poco explorada, debido a que es un área dedicada principalmente a la agricultura y quedan pocos manchones de bosque tropical caducifolio y matorral subtropical. Los objetivos del estudio fueron conocer la composición florística en el Cerro del Veinte, comparar la riqueza de especies con otras localidades que presentan el mismo tipo de vegetación y determinar el estado de conservación de las especies de acuerdo a la NOM-059 SEMARNAT2010. El muestreo fue por medio de transectos libres de aproximadamente $1 \mathrm{~km}$ en las Barrancas La Escondida y El Paiste. Se obtuvo en total 59 familias, 137 géneros, 171 especies y cuatro variedades. Las familias mejor representadas son Asteraceae, Fabaceae y Pteridaceae. De acuerdo al estimador Chao 2 el esfuerzo de muestreo en el área de estudio fue de 87 $\%$. La afinidad florística en el Cerro del Veinte fue mayor con la Hoya de Rincón de Parangueo (38\%) y Sierra de Pénjamo (32\%). Además, se tienen tres nuevas especies reportadas para Guanajuato, Govenia lagenophora y Sacoila lanceolata (Orchidaceae) y Solanum edmundoi (Solanaceae). Y los taxones Cedrela odorata y Erythrina coralloides están incluidas en la NOM-059-SEMARNAT-2010.

Cerro del Veinte, Estimador Chao 2, Orchidaceae

Citation: HERNÁNDEZ-HERNÁNDEZ, Victoria, RAMOS-LÓPEZ, Luis Fernando and COLLI-MULL, Juan Gualberto. Floristic composition in deciduous tropical forest to west of Irapuato, Guanajuato. Journal of Environmental Sciences and Natural Resources. 2019, 5-15: 36-43

\footnotetext{
* Correspondence to Author (email: vihernandez@itesi.edu.mx)

$\dagger$ Researcher contributing first author.
} 


\section{Introduction}

Mexico is a country with great floristic diversity with a record of 23314 species of vascular plants (Villaseñor, 2016), also presents different types of vegetation throughout its territory, one of these communities is the tropical deciduous forest (BTC) or Low deciduous forest (Rzedowski, 2006). The tropical deciduous forest is characterized by having a very diverse flora and approximately $60 \%$ of its elements are endemic. The distribution of the forest in the Bajío region has a semi-warm climate with the lowest minimum temperature of $6^{\circ} \mathrm{C}$ and altitudes above 1700 meters above sea level (Trejo-Vázquez, 1999). The BTC on flat land has disappeared due to the ease of access to establish cultivation areas or agostaderos, causing fragmentation of isolated locations that are currently part of secondary vegetation (Zamudio, 2012).

In the state of Guanajuato, the BTC originally occupied large areas, to the south in the biogeographic province that corresponds to the Neovolcanic Axis where it mainly covered hillsides and ravines; but in the last 20 years its extension has decreased, due to agriculture and logging; Currently, there is a record of less than $10 \%$ of the total area of the state, and there are only fragments in isolated locations or becoming secondary vegetation such as subtropical scrubland (Rzedowski and Calderón de Rzedowski, 1987; Zamudio, 2012).

Another factor that has influenced the loss of the BTC is the immoderated logging of some timber species used in construction, such as poles and fuels (Rzedowski, 2006).

The floristic components of the tropical deciduous forest are variable depending on each zone and even this plant community in the country is scarcely similar in its flora (Rzedowski and Calderón de Rzedowski, 2013). The presence or absence of some floristic elements depends on environmental factors such as temperature, humidity and precipitation, in addition these forests generally do not have a dominant species because they are very diverse.
In Guanajuato it is common to find tree species such as Lysiloma microphylla (stick prieto), Albizia plurijuga (white stick), Bursera cuneata (copal), Ceiba aesculifolia (ceiba or pochote), Ipomoea murucoides (huntress), Vachellia farnesiana and V. schaffneri ( huizache), V. pennatula (tepame), Bursera fagaroides (cuajiote or copal), Opuntia streptacantha (nopal cardón), Heliocarpus terebinthinaceus, Myrtillocactus geometrizans (garambullo), Agonandra racemosa, Eysenhardtia polystachya (sweet stick), coral stick) Senna polyantha, Parkinsonia aculeata (reed), Prosopis laevigata (mesquite), Casimiroa edulis (white sapote). And shrub species such as Calliandra humilis, Condalia velutina, Senna floribunda, Mimosa aculeaticarpa and Verbesina sphaerocephala (Rzedowski, 2006; Zamudio, 2012). In Guanajuato and in other states there is no dominant species in the BTC, but the presence and abundance of Fabaceae family species that has persisted and evolved in these environments is evident (Hernández-Ramírez and GarcíaMéndez, 2015).

The vascular flora in the state of Guanajuato is estimated at 3,206 species, of which 3032 are flowering plants, 150 lycopods and ferns and 24 gymnosperms and only seven taxa are reported as endemic in the entity (Villaseñor, 2016).

The floristic studies in the municipality of Irapuato are few, López and Martínez (2009) in the ANP Cerro de Arandas recorded a list of 22 taxa, the dominant species being Vachelia farnesiana and Ipomoea murucoides and Hernández-Hernández et al., (2017) 30 species of lycopodia and ferns report in Tamahula, Cerro del Veinte.

The objectives of the present study were to obtain the floristic list in two canyons of Cerro del Veinte to establish a comparison with other localities of Guanajuato that present the same type of vegetation (BTC) and also determine if any of the species is in some criterion of conservation according to NOM059- SEMARNAT-2010 (SEMARNAT, 2010).

\section{Study area}

The Cerro del Veinte is located in the western portion of the municipality of Irapuato and northeast of Abasolo, occupies an area of approximately 6120.52 ha (INEGI, 2015).

HERNÁNDEZ-HERNÁNDEZ, Victoria， RAMOS-LÓPEZ, Lui Fernando and COLLI-MULL, Juan Gualberto. Floristic composition in deciduous tropical forest to west of Irapuato, Guanajuato. Journal of Environmental Sciences and Natural Resources. 2019 
The study covered two ravines located in the community of Cuchicuato, Irapuato, 1) Barranca la Escondida is located south of the hill at $20^{\circ} 41^{\prime} 26.6^{\prime \prime} \mathrm{N}$ and $101^{\circ} 30^{\prime} 18.6^{\prime \prime} \mathrm{W}$, at an altitude range between 1815 to 2023 meters above sea level and 2) Barranca el Paiste is located east of the hill at $20^{\circ} 41^{\prime} 49.47^{\prime \prime} \mathrm{N}$ and $101^{\circ} 30^{\prime} 18.0^{\prime \prime} \mathrm{W}$, at 1866 to 2094 meters above sea level (Figure 1).

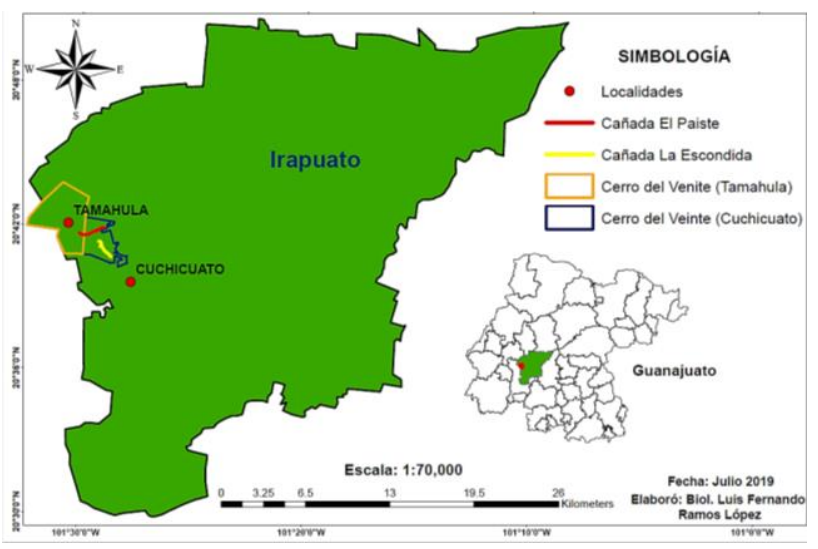

Figure 1 Geographical location of Cerro del Veinte, Irapuato, Gto.

It has a sub-humid semi-warm climate, with an annual average cumulative precipitation of $688 \mathrm{~mm}$, the rainiest month is August with 160 to $170 \mathrm{~mm}$ and the one with the lowest rainfall is February with $5 \mathrm{~mm}$. The average annual temperature is $18.7^{\circ} \mathrm{C}$, the warmest month is May with $28^{\circ} \mathrm{C}$ and the coldest January with $16^{\circ} \mathrm{C}$ (INEGI, 2015).

The municipality of Irapuato is part of the Lerma River basin (hydrological region 12), which in turn is divided into three sub-basins, 1) Guanajuato, 2) Temacatío and 3) Pénjamo Irapuato-Silao; This last sub-basin is where the study area is located (Cruz-José et al., 2012).

The type of soil present in the hill is vertisol, they are shallow soils of $50 \mathrm{~cm}$, shallow and stony brown to black, clayey texture with moisture retention capacity and low organic matter (Quijano-Carranza et al., 2012).

\section{Methodology}

The collection of vascular plants was carried out during the period from February 2015 to January 2016, both in the rainy and dry season; the sampling was by the method of free transects of approximately one kilometer (Mostacedo and Fredericksen, 2000) in the two canyons of Cerro del Veinte.
The identification of the plants was with the help of specialized literature and field guides (Rzedowski and Guevara-Féfer, 1992; Mickel and Smith, 2004; Calderón de Rzedowski and Rzedowski, 2004; Cretcher et al., 2010; Sahagún-Godínez et al., 2014). Herbalized material was deposited in the collection of the Higher Technological Institute of Irapuato.

\section{Statistic analysis}

The sampling effort was measured by means of species accumulation curves, based on random sampling. Species richness was calculated using the Chao 2 diversity estimator (JiménezValverde and Hortal; 2003), in the EstimateS 9.1.0 program (Colwell, 2013).

The Sprensen Similarity Index was applied to estimate the number of shared species, with four locations in Guanajuato, the criterion was that the localities presented tropical deciduous forest, and thus determine the similarity between sites based on the number of related species (Moreno, 2001).

\section{Results}

A total of 319 specimens of vascular plants corresponding to 59 families, 137 genera, 171 species and 4 varieties were reviewed. The families with the highest number of species are Asteraceae (20), Fabaceae (16) and Pteridaceae (14). The largest number of species corresponds to the herbaceous stratum as elements of the undergrowth, the tree stratum with 20 species that constitutes the major part of the vegetation cover and vines with 11 taxa (Annex 1).

The species included in NOM-059SEMARNAT-2010 are Cedrela odorata subject to special protection and Erythrina coralloides as threatened.

Some rare species that are found only once on the hill, are Dichromanthus cinnabarinus, Govenia lagenophora and Sacoila lanceolata belonging to the Orchidaceae family; Jarilla caudata is an edible plant in the study area; other scarce taxa are Pavonia candida and Solanum edmundoi and some Bursera penicillata, Colubrina triflora and Manihot caudata trees. 
The Chao 2 estimator predicts 212 species (with $95 \%$ completeness) and so far $87 \%$ of the flora in the Cerro canyons has been inventoried with the observed wealth of 175 taxa (Fig. 2).

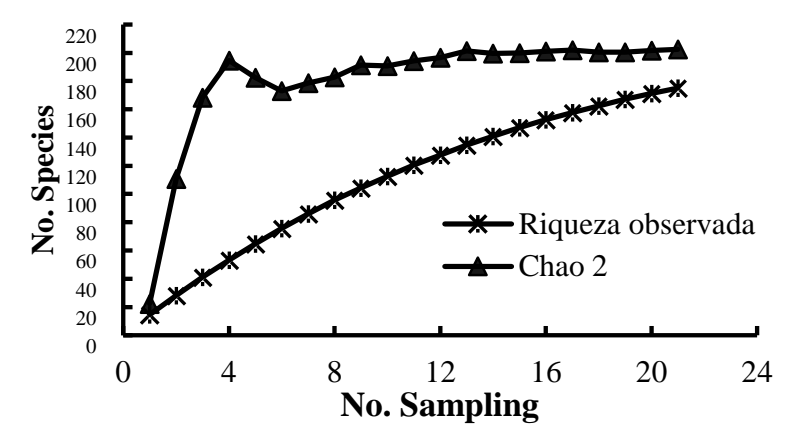

Figure 2 Accumulation curve of species present in the El Paiste and La Escondida Canyon of Cerro del Veinte

The floristic similarity of the BTC in the Cerro del Veinte and other towns of Guanajuato was greater with Hoya de Rincón de Parangueo (38\%) and Sierra de Pénjamo (32\%) and less with Cerro de Arandas and San José de Iturbide (Table 2 ).

Table 2. Floristic comparison between communities with tropical deciduous forest in Guanajuato. In parentheses the total number of species of each shared area / taxa and altitude is presented.

\begin{tabular}{|l|r|}
\hline & $\begin{array}{l}\text { Hill of Twenty } \\
(175 \mathrm{spp} .)\end{array}$ \\
Locations & $\begin{array}{l}\text { 2036 m. } \\
\text { Similarity } \\
\text { percentage }\end{array}$ \\
\hline $\begin{array}{l}\text { Cerro de Arandas, Irapuato (22/11 } \\
\text { spp.), 2000 m }\end{array}$ & 11.6 \\
\hline $\begin{array}{l}\text { Hoya Rincon de Parangueo (228/77 } \\
\text { spp.), 1850 m }\end{array}$ & 38 \\
\hline $\begin{array}{l}\text { Sierra de Pénjamo } \\
\text { (258/74 spp.), 1783-1950 m }\end{array}$ & 34 \\
\hline $\begin{array}{l}\text { San Jose Iturbide } \\
(69 / 10 \text { spp.), 2100-2500 m }\end{array}$ & 8 \\
\hline
\end{tabular}

\section{Discussion}

The tropical deciduous forest is characterized by presenting great floristic diversity; however, at a specific level there is no complete estimate of the species that inhabit these Forests, but there is a report of 749 genera of phanerogams of which 96 are dominant and frequently grow in Mexico (Rzedowsky and Calderón de Rzedowsky, 2013), for the hill of Twenty there is a total of 124 genera that is $16.55 \%$ of those recognized in the country and the dominant and similar genera corresponds to $16.66 \%$;
Trejo-Vázquez (1999) mentions the low floristic similarity of the BTC between the different entities of the Mexican Republic.

In the Bajío Guanajuatense region, the BTC is regularly distributed in cerrile portions and at altitudes greater than 1800 meters above sea level (Trejo-Vázquez, 1998), Cerro del Veinte presents these conditions, that is, it is an area with steep slopes and is located between 1974 to 2036 masl.

The families of angiosperms important for their abundance in the BTC are Asteraceae, Fabaceae, Malvaceae, Acanthaceae, Cucurbitaceae, Malpighiaceae, Euphorbiaceae and Sapindaceae (Rzedowski and Calderón de Rzedowsky, 2013), in the Hill the best represented families are Asteraceae (20 spp.) and Fabaceae (16 spp.) with the highest number of species, in Acanthaceae and Euphorbiaceae there are 6 species and the remaining families with only two taxa; Aguilera (1991) in the crater Hoya de Rincón de Parangueo also reported 22 species of Asteraceae and in Fabaceae 23.

Another relevant group, although scarcely diverse in the BTC are lycopodia and ferns, in the Sierra de Pénjamo 37 species were found and the representative family is Pteridaceae with 16 (Hernández-Hernández et al., 2016), this family was also abundant in The work area with 14 taxa. The species included in NOM-059-SEMARNAT-2010 are Cedrela odorata in the category subject to special protection and Erythrina coralloides as threatened.

On the other hand, Manihot caudata is a rare species in the shoal (Aguilera, 1991) and Bursera penicillata is in danger of disappearance in the shoal (Rzedowski and Guevara-Féfer, 1992). The species Govenia lagenophora and Sacoila lanceolata belong to the Orchidaceae family and are new records for the state of Guanajuato, it had not been inventoried in the literature (Zamudio and Galván-Villanueva，2011; Villaseñor, 2016), these orchids are of terrestrial habit and Very few in the BTC, they usually grow in places with favorable atmospheric humidity, at higher altitudes as is the case in the study area and are also considered as sensitive to disturbance (Rzedowsky and Calderón de Rzedowsky, 2013). 
Taking into account these abiotic factors, it can be affirmed that the state of conservation in the El Paiste ravine of Cerro del Veinte is suitable for the establishment of these orchids, on the other hand in the La Escondida ravine, the Dichromanthus cinnabarinus orchid was already registered with Priority in the state (Zamudio and Galván-Villanueva, 2011).

The species Solanum edmundoi (Solanaceae) was recently reported for Mexico, the type specimen described comes from the Sierra de Cacoma, Jalisco (Cuevas-Guzmán and Núñez-López; 2015; Villaseñor, 2016), and had not been found in Guanajuato and grows in the El Paiste ravine in a preserved area. According to the Chao 2 estimator, the sampling effort was appropriate on the hill of Twenty, $87 \%$ was inventoried and 37 species would be missing to reach the asymptote.

The similarity in the composition and richness of BTC species in Cerro del Veinte compared to the four areas of Guanajuato, had greater affinity with the Sierra de Pénjamo by sharing 74 species (Guadián-Marín, 2012) and the Hoya de Rincón de Parangueo with 77 taxa (Aguilera, 1991) and was smaller with San José de Iturbide with only 10 species in common (Gutiérrez and Solano, 2014), in the Guanajuatense basin this vegetable community is distributed between 1700 to $2000 \mathrm{~m}$, within higher altitude areas in the Mexican Republic (Rzedowski and Calderón de Rzedowski, 1987). In addition, the floristic composition of the BTC usually differs mainly due to abiotic factors such as climate, altitude and geographical arrangement of each region and the floristic affinity of most BTC taxa are of Neotropical origin (Trejo-Vázquez, 1999).

\section{Conclusion}

The floristic diversity of the BTC in the Cerro del Veinte consists of 175 taxa of vascular plants, where conservation indicator species such as terrestrial orchids are still growing. According to the Chao 2 estimator, $13 \%$ of the vascular flora in the hill remains to be collected, so it is recommended to continue with the botanical exploration.

This study is a contribution to floristic knowledge in Irapuato, Guanajuato and could serve as a basis for proposing the area in conservation programs, being a relict of BTC in the municipality.

\section{Thanks}

The authors thank Mariana Jasso Barrón for her help in the field trips and the people of the community of Cuchicuato, Irapuato for the facilities granted during the visit to Cerro del Veinte.

\section{References}

Aguilera, G. L. I. (1991). Estudio florístico y sinecológico de la vegetación en el cráter "Hoya de Rincón de Parangueo", Valle de Santiago, Gto. Tesis de maestría. Colegio de Postgraduados. México. 99 pp.

Calderón de Rzedowski, G. y Rzedowski, J. (2004). Manual de malezas de la región de Salvatierra, Guanajuato. Flora del Bajío y de Regiones Adyacentes XX, 1-320.

Colwell, R. K. (2013). EstimateS: Statistical estimation of species richness and shared species from samples. Version 9. Persistent URL <purl.oclc.org/estimates>.

Cretcher, R., Rohan, D. y Rzedowski, J. (2010). Flores silvestres de San Miguel de Allende. Jardín Botánico Charco del Ingenio y R \& D Publishing. 175 pp.

Cruz-José, J. L., García-González, M. R., Acevedo-Torres, J. B., Ángeles-Gómez, J. C., Fuentes-Hernández, V. y Martínez-González, J. E. (2012). Aspectos de la hidrología en el estado. En: La Biodiversidad en Guanajuato: Estudio de Estado Vol. I. Comisión Nacional para el Conocimiento y Uso de la Biodiversidad (CONABIO)/Instituto de Ecología del Estado de Guanajuato (IEE). México. pp. 46-62.

Cuevas-Guzmán, R. y Núñez López, N. M. (2015). Solanum edmundoi (Solanaceae), una especie nueva de bejuco con aguijones del occidente de México. Revista Mexicana de Biodiversidad 86, 293-297.

Guadián-Marín, J. I. (2012). Flora y vegetación de la Sierra de Pénjamo, Guanajuato (México). Tesis de licenciatura. Universidad Michoacana de San Nicolás de Hidalgo, Facultad de Biología. Morelia, Michoacán, México. 157 pp.

Gutiérrez, J. y Solano, E. (2014). Afinidades florísticas y fitogeográficas de la vegetación del municipio de San José Iturbide, Guanajuato, México. Acta Botánica Mexicana 107, 27-65.

HERNÁNDEZ-HERNÁNDEZ， Victoria， RAMOS-LÓPEZ， Luis Fernando and COLLI-MULL, Juan Gualberto. Floristic composition in deciduous tropical forest to west of Irapuato, Guanajuato. Journal of Environmental Sciences and Natural Resources. 2019 
Hernández-Hernández, V., González-García, S. M. y Colli-Mull, J.G. (2016). Licopodios y helechos de la Sierra de Pénjamo, Guanajuato. Revista de Ciencias Ambientales y Recursos Naturales 2, 44-50.

Hernández-Hernández V., Vargas-Gallaga C. E., Colli Mull J. G. y Jasso-Barrón M. (2017). Listado de licopodios y helechos del Cerro del Veinte, Irapuato, Guanajuato, México. Revista de Ciencias Ambientales y Recursos Ambientales 7, 39-48.

Hernández-Ramírez, A. M. y García-Méndez, S. (2015). Diversidad, estructura y regeneración de la selva tropical estacionalmente seca de la Península de Yucatán, México. Revista de Biología Tropical 63, 603-616.

INEGI (Instituto Nacional de Estadística y Geografía). (2015). SIATL (Simulador de Flujos de Agua de Cuencas Hidrológicas). Consultado en: http://antares.inegi.org.mx/analisis/red_hidro/SI ATL/\#. Fecha de consulta: 27 de Octubre del 2015.

Jiménez-Valverde, A. y Hortal, J. (2003). Las curvas de acumulación de especies y la necesidad de evaluar la calidad de los inventarios biológicos. Revista Ibérica de Aracnología 8, 151-161.

López, J. L. N. y Martínez, M. D. de S. (2009). Estudio florístico y de la vegetación del Cerro de Arandas en Irapuato, Guanajuato, Memorias del Programa Verano de la Ciencia 2009 y $11^{\circ}$ Verano de la Ciencia de la Región Centro. Universidad Autónoma de Querétaro.

Mickel, J.T. y Smith, A. (2004). The Pteridophytes of Mexico. Memoirs of the New York Botanical Garden 88, 1-1054.

Moreno, C. E. (2001). Métodos para medir la biodiversidad. M \& T-Manuales y Tesis SEA. 1, 1-83.

Mostacedo, B. y Fredericksen, T. S. (2000). Manual de métodos básicos de muestreo y análisis en Ecología Vegetal. El País. Bolivia. $87 \mathrm{pp}$.
Quijano-Carranza, J. A. y Rocha-Rodríguez, R. (2012). Los suelos de Guanajuato. En: La Biodiversidad en Guanajuato: Estudio de Estado Vol. I. Comisión Nacional para el Conocimiento y Uso de la Biodiversidad (CONABIO)/Instituto de Ecología del Estado de Guanajuato (IEE). México. pp. 74-81.

Rzedowski, J. y Calderón de Rzedowski, G. (1987). El bosque tropical caducifolio de la región mexicana del Bajío. Trace 12, 12-21.

Rzedowski J. y Guevara-Féfer F. (1992). Burseraceae. Flora del Bajío y de Regiones Adyacentes 3, 1-46.

Rzedowski, J. y Calderón de Rzedowski, G. (2013). Datos para la apreciación de la flora fanerogámica del bosque tropical caducifolio de México. Acta Botánica Mexicana 102, 1-23.

Sahagún-Godínez, E., M. A. Macías R.., P. Carrillo R., N. Larrañaga G. y J.A. Vázquez G. (2014). Guía de campo de los arboles tropicales de la Barranca del río Santiago en Jalisco, México. Universidad Autónoma de Guadalajara. $313 \mathrm{pp}$.

SEMARNAT (Secretaría de Medio Ambiente y Recursos Naturales). (2010). Norma Oficial Mexicana NOM-059-SEMARNAT-2010, Protección ambiental-Especies nativas de México de flora y fauna silvestres-Categorías de riesgo y especificaciones para su inclusión, exclusión o cambio-Lista de especies en riesgo. Diario Oficial de la Federación. 30 de diciembre de 2010, Segunda Sección. México. 77 pp.

Trejo-Vázquez, I. (1999). El clima de la selva baja caducifolia en México. Investigaciones Geográficas Boletín 39. Instituto de Geografía, UNAM. México, D.F. 40-52 pp.

Villaseñor, J. L. (2016). Checklist of the native vascular plants of Mexico. Revista Mexicana de biodiversidad 87, 559-902.

Zamudio, S. y Galván-Villanueva, R. (2011). La diversidad vegetal del estado de Guanajuato, México. Flora del Bajío y de Regiones Adyacentes. XXVII, $101 \mathrm{pp}$.

Zamudio, R. S. (2012). Diversidad de ecosistemas del estado de Guanajuato. En: La Biodiversidad de Guanajuato, Estudio de estado Vol. II. Comisión Nacional para el Conocimiento y Uso de la Biodiversidad/Instituto de Ecología del Estado de Guanajuato. pp. 21-55. 
Anexo 1 List of families, genera and species present in the ravines El Paiste (PTE) y La Escondida (ESC) del Cerro del Veinte. $\mathrm{H}=$ Herbácea, $\mathrm{B}=$ Bejuco, Arb = Arbusto, $\mathrm{A}=$ Árbol.

\begin{tabular}{|c|c|c|c|}
\hline \multirow{2}{*}{ Family / Species } & \multicolumn{2}{|c|}{ Ravine } & \multirow[t]{2}{*}{ Habit } \\
\hline & Pte & Esc & \\
\hline \multicolumn{4}{|l|}{ Licopodios } \\
\hline \multicolumn{4}{|l|}{ Selaginellaceae } \\
\hline \begin{tabular}{|l|} 
Selaginella Delicatissima \\
\end{tabular} & $\mathrm{X}$ & & $\mathrm{H}$ \\
\hline Selaginella Lepidophylla & $\mathrm{X}$ & $\mathrm{X}$ & $\mathrm{H}$ \\
\hline Selaginella Rupincola & $\mathrm{X}$ & $\mathrm{X}$ & $\mathrm{H}$ \\
\hline \multicolumn{4}{|l|}{ Helechos } \\
\hline \multicolumn{4}{|l|}{ Aspleniaceae } \\
\hline Asplenium Exiguum & $\mathrm{X}$ & & $\mathrm{H}$ \\
\hline Asplenium Gentryi & $\mathrm{X}$ & $\mathrm{X}$ & $\mathrm{H}$ \\
\hline Cystopteridaceae & & & $\mathrm{H}$ \\
\hline Cystopterys Fragilis & $\mathrm{X}$ & & $\mathrm{H}$ \\
\hline \multicolumn{4}{|l|}{ Polypodiaceae } \\
\hline Pleopeltis Polypodioides & $\mathrm{X}$ & & $\mathrm{H}$ \\
\hline Pleopeltis Thyssanolepis & $\mathrm{X}$ & $\mathrm{X}$ & $\mathrm{H}$ \\
\hline \multicolumn{4}{|l|}{ Pteridaceae } \\
\hline Adiantum Concinnum & $\mathrm{X}$ & $\mathrm{X}$ & $\mathrm{H}$ \\
\hline Argyrochosma Incana & $\mathrm{X}$ & & $\mathrm{H}$ \\
\hline Argyrochosma Pallens & & $\mathrm{X}$ & $\mathrm{H}$ \\
\hline Astrolepis Sinuata & $\mathrm{X}$ & $\mathrm{X}$ & $\mathrm{H}$ \\
\hline Bommeria Pedata & & $\mathrm{X}$ & $\mathrm{H}$ \\
\hline Cheilanthes Lozanii Var. Seemannii & & $\mathrm{X}$ & $\mathrm{H}$ \\
\hline Gaga Kaulfussii & $\mathrm{X}$ & & $\mathrm{H}$ \\
\hline Myriopteris Allosuroides & & $\mathrm{X}$ & $\mathrm{H}$ \\
\hline Myriopteris Aurea & $\mathrm{X}$ & $\mathrm{X}$ & $\mathrm{H}$ \\
\hline Myriopteris Cucullans & $\mathrm{X}$ & $\mathrm{X}$ & $\mathrm{H}$ \\
\hline Myriopteris Myriophylla & $\mathrm{X}$ & $\mathrm{X}$ & $\mathrm{H}$ \\
\hline Pellaea Cordifolia & $\mathrm{X}$ & $\mathrm{X}$ & $\mathrm{H}$ \\
\hline Pellaea Ovata & $\mathrm{X}$ & & $\mathrm{H}$ \\
\hline Pellaea Villosa & $\mathrm{X}$ & & $\mathrm{H}$ \\
\hline Woodsiaceae & & & \\
\hline Woodsia Mexicana & $\mathrm{X}$ & & $\mathrm{H}$ \\
\hline Woodsia Mollis & $\mathrm{X}$ & & $\mathrm{H}$ \\
\hline Dicotyledoneae & & & \\
\hline Acanthaceae & & & \\
\hline Anisacanthus Pumilus & $\mathrm{X}$ & & Arb \\
\hline Dyschoriste Hirsutissima & $\mathrm{X}$ & $\mathrm{X}$ & $\mathrm{H}$ \\
\hline Henrya Insularis & $\mathrm{X}$ & $\mathrm{X}$ & $\mathrm{H}$ \\
\hline Justicia Candicans & & $\mathrm{X}$ & Arb \\
\hline \begin{tabular}{|l|} 
Ruellia Lactea \\
\end{tabular} & $\mathrm{X}$ & $\mathrm{X}$ & $\mathrm{H}$ \\
\hline Tetramerium Nervosum & $\mathrm{X}$ & $\mathrm{X}$ & $\mathrm{H}$ \\
\hline Amaranthaceae & & & \\
\hline Amaranthus Hybridus & $\mathrm{X}$ & & $\mathrm{H}$ \\
\hline \begin{tabular}{|l} 
Gomphrena Serrata \\
\end{tabular} & $\mathrm{X}$ & $\mathrm{X}$ & $\mathrm{H}$ \\
\hline Iresine Grandis & $\mathrm{X}$ & $\mathrm{X}$ & Arb \\
\hline Apiaceae & & & \\
\hline Prionosciadium Watsonii & $\mathrm{X}$ & & $\mathrm{H}$ \\
\hline Apocynaceae & & & \\
\hline Asclepias Linaria & $\mathrm{X}$ & & $\mathrm{H}$ \\
\hline Funastrum Pannosum & & $\mathrm{X}$ & $\mathrm{B}$ \\
\hline Mandevilla Foliosa & & $\mathrm{X}$ & Arb \\
\hline Matelea Chrysantha & $\mathrm{X}$ & & $\mathrm{B}$ \\
\hline Asteraceae & & & \\
\hline Acourtia Reticulata & $\mathrm{X}$ & & $\mathrm{H}$ \\
\hline \begin{tabular}{|l} 
Ageratum Corymbosum \\
\end{tabular} & $\mathrm{X}$ & & $\mathrm{H}$ \\
\hline Barkleyanthus Salicifolius & & & \\
\hline Bidens Bigelovii & $\mathrm{X}$ & & $\mathrm{H}$ \\
\hline Bidens Odorata & & $\mathrm{X}$ & $\mathrm{H}$ \\
\hline Bidens Triplinervia & $\mathrm{X}$ & & $\mathrm{H}$ \\
\hline Erigeron Bonariensis & $\mathrm{X}$ & & $\mathrm{H}$ \\
\hline Dahlia Coccinea & $\mathrm{X}$ & & $\mathrm{H}$ \\
\hline Galeana Pratensis & $\mathrm{X}$ & & $\mathrm{H}$ \\
\hline Lactuca Serriola & $\mathrm{X}$ & & $\mathrm{H}$ \\
\hline Montanoa Bipinnatifida & $\mathrm{X}$ & $\mathrm{X}$ & Arb \\
\hline Psacalium Platylepis & $\mathrm{X}$ & & $\mathrm{H}$ \\
\hline Roldana Heracleifolius & & $\mathrm{X}$ & Arb \\
\hline Barkleyanthus Salicifolius & $\mathrm{X}$ & & Arb \\
\hline Sonchus Oleraceus & $\mathrm{X}$ & & $\mathrm{H}$ \\
\hline Tagetes Lucida & $\mathrm{X}$ & & $\mathrm{H}$ \\
\hline Tagetes Lunulata & $\mathrm{X}$ & $\mathrm{X}$ & $\mathrm{H}$ \\
\hline Tagetes Micrantha & $\mathrm{X}$ & & $\mathrm{H}$ \\
\hline Trigonospermuт Аппиит & & $\mathrm{X}$ & $\mathrm{H}$ \\
\hline Vernonia Alamanii & $\mathrm{X}$ & $\mathrm{X}$ & Arb \\
\hline Zinnia Peruviana & $\mathrm{X}$ & $\mathrm{X}$ & $\mathrm{H}$ \\
\hline Begoniaceae & & & \\
\hline Begonia Gracilis & $\mathrm{X}$ & $X$ & $\mathrm{H}$ \\
\hline
\end{tabular}

ISSN 2444-4936

ECORFAN® All rights reserved

\begin{tabular}{|c|c|c|c|}
\hline \multicolumn{4}{|l|}{ Bignoniaceae } \\
\hline Tecoma Stans & & $\mathrm{X}$ & Arb \\
\hline \multicolumn{4}{|l|}{ Brassicaceae } \\
\hline Lepidium Virginicum & $\mathrm{X}$ & & $\mathrm{H}$ \\
\hline \multicolumn{4}{|l|}{ Burseraceae } \\
\hline Bursera Bipinnata & & $\mathrm{X}$ & $\mathrm{Ar}$ \\
\hline \begin{tabular}{|l} 
Bursera Fagaroides \\
\end{tabular} & & $\mathrm{X}$ & $\mathrm{Ar}$ \\
\hline \begin{tabular}{|l|} 
Bursera Palmeri \\
\end{tabular} & $\mathrm{X}$ & & $\mathrm{Ar}$ \\
\hline Bursera Penicillata & & $\mathrm{X}$ & $\mathrm{Ar}$ \\
\hline \multicolumn{4}{|l|}{ Cactaceae } \\
\hline Coryphantha Elephantidens & $\mathrm{X}$ & & $\mathrm{H}$ \\
\hline Mammillaria Magnimamma & $\mathrm{X}$ & $\mathrm{X}$ & $\mathrm{H}$ \\
\hline Myrtillocactus Geometrizans & $\mathrm{X}$ & $\mathrm{X}$ & $\mathrm{H}$ \\
\hline Peniocereus Serpentinus & $\mathrm{X}$ & & $\mathrm{H}$ \\
\hline \begin{tabular}{|l|} 
Stenocereus Pruinosus \\
\end{tabular} & $\mathrm{X}$ & $\mathrm{X}$ & $\mathrm{H}$ \\
\hline Cannabaceae & & & \\
\hline Celtis Caudata & $\mathrm{X}$ & $\mathrm{X}$ & $\mathrm{Ar}$ \\
\hline Caricaceae & & & \\
\hline Jarilla Caudata & & $\mathrm{X}$ & $\mathrm{H}$ \\
\hline Convolvulaceae & & & \\
\hline \begin{tabular}{|l|} 
Evolvulus Alsinoides \\
\end{tabular} & & $\mathrm{X}$ & $\mathrm{H}$ \\
\hline \begin{tabular}{|l|} 
Ipomoea Hederifolia \\
\end{tabular} & $\mathrm{X}$ & & $\mathrm{B}$ \\
\hline Ipomoea Murucoides & $\mathrm{X}$ & $\mathrm{X}$ & $\mathrm{Ar}$ \\
\hline Ipomoea Purpurea & $\mathrm{X}$ & $\mathrm{X}$ & $\mathrm{T}$ \\
\hline Crassulaceae & & & \\
\hline Echeveria Subrigida & & $\mathrm{X}$ & $\mathrm{H}$ \\
\hline Sedum Ebracteatum & & $\mathrm{X}$ & $\mathrm{H}$ \\
\hline Sedum Jaliscanum & $\mathrm{X}$ & & $\mathrm{H}$ \\
\hline Cucurbitaceae & & & \\
\hline Cyclanthera Ribiflora & $\mathrm{X}$ & & B \\
\hline Schizocarpum Parviflorum & $\mathrm{X}$ & $\mathrm{X}$ & $\mathrm{T}$ \\
\hline Euphorbiacea & & & \\
\hline Cnidoscolus Angustidens & & $\mathrm{X}$ & $\mathrm{H}$ \\
\hline Croton Ciliatoglandulifer & $\mathrm{X}$ & $\mathrm{X}$ & Arb \\
\hline Croton Morifolius & $\mathrm{X}$ & $\mathrm{X}$ & Arb \\
\hline Euphorbia Tanquahuete & $\mathrm{X}$ & $\mathrm{X}$ & $\mathrm{Ar}$ \\
\hline Jatropha Dioica & & $\mathrm{X}$ & Arb \\
\hline Manihot Caudata & $\mathrm{X}$ & $\mathrm{X}$ & $\mathrm{Ar}$ \\
\hline Fabaceae & & & \\
\hline Brongniartia Intermedia & $\mathrm{X}$ & $\mathrm{X}$ & Arb \\
\hline Cologania Broussonetii & $\mathrm{X}$ & $\mathrm{X}$ & $\mathrm{T}$ \\
\hline Dalea Foliolosa & & $\mathrm{X}$ & $\mathrm{H}$ \\
\hline Erythrina Coralloides & $\mathrm{X}$ & $\mathrm{X}$ & $\mathrm{Ar}$ \\
\hline Eysenhardtia Polystachya & & $\mathrm{X}$ & $\mathrm{Ar}$ \\
\hline Hesperalbizia Occidentalis & $\mathrm{X}$ & $\mathrm{X}$ & $\mathrm{Ar}$ \\
\hline Lysiloma Microphylla & $\mathrm{X}$ & $\mathrm{X}$ & $\mathrm{Ar}$ \\
\hline Macroptilium Atropurpureum & & $\mathrm{X}$ & $\mathrm{T}$ \\
\hline Macroptilium Gibbosifolium & $\mathrm{X}$ & & $\mathrm{T}$ \\
\hline Nissolia Microptera & $\mathrm{X}$ & $\mathrm{X}$ & $\mathrm{T}$ \\
\hline \begin{tabular}{|l} 
Phaseolus Vulgaris \\
\end{tabular} & $\mathrm{X}$ & $\mathrm{X}$ & $\mathrm{T}$ \\
\hline Senna Hirsuta Var. Glaberrima & $\mathrm{X}$ & & Arb \\
\hline \begin{tabular}{|l} 
Senna Polyantha \\
\end{tabular} & $\mathrm{X}$ & $\mathrm{X}$ & $\mathrm{Ar}$ \\
\hline Vachellia Farnesiana & $\mathrm{X}$ & $\mathrm{X}$ & Arb \\
\hline Vachellia Schaffneri & $\mathrm{X}$ & & Arb \\
\hline \begin{tabular}{|l|} 
Zapoteca Formosa \\
\end{tabular} & $\mathrm{X}$ & $\mathrm{X}$ & Arb \\
\hline Juglandaceae & & & \\
\hline \begin{tabular}{|l} 
Juglans Mollis \\
\end{tabular} & $\mathrm{X}$ & $\mathrm{X}$ & $\mathrm{Ar}$ \\
\hline Loasaceae & & & \\
\hline Mentzelia Aspera & & $\mathrm{X}$ & $\mathrm{H}$ \\
\hline Mentzelia Hispida & $\mathrm{X}$ & & $\mathrm{H}$ \\
\hline Loranthaceae & & & \\
\hline Psittacanthus Palmeri & & $\mathrm{X}$ & $\mathrm{H}$ \\
\hline Lythraceae & & & \\
\hline \begin{tabular}{|l} 
Cuphea Wrightii Var. Wrightii \\
\end{tabular} & & $\mathrm{X}$ & $\mathrm{H}$ \\
\hline Heimia Salicifolia & $\mathrm{X}$ & $\mathrm{X}$ & Arb \\
\hline Malpighiaceae & & & \\
\hline Aspicarpa Cynanchoides & & $\mathrm{X}$ & B \\
\hline Heteropterys Brachiata & $\mathrm{X}$ & $\mathrm{X}$ & B \\
\hline Malvaceae & & & \\
\hline Anoda Maculata & & $\mathrm{X}$ & $\mathrm{H}$ \\
\hline Ceiba Aesculifolia & $\mathrm{X}$ & $\mathrm{X}$ & $\mathrm{Ar}$ \\
\hline Heliocarpus Terebinthinaceus & $\mathrm{X}$ & $\mathrm{X}$ & $\mathrm{Ar}$ \\
\hline Pavonia Candida & $\mathrm{X}$ & $\mathrm{X}$ & Arb \\
\hline Meliaceae & & & \\
\hline Cedrela Odorata & $\mathrm{X}$ & & $\mathrm{Ar}$ \\
\hline Nyctaginaceae & & & \\
\hline Mirabilis Jalapa & $\mathrm{X}$ & & $\mathrm{H}$ \\
\hline \begin{tabular}{|l|} 
Mirabilis Longiflora \\
\end{tabular} & & $\mathrm{X}$ & $\mathrm{H}$ \\
\hline \begin{tabular}{|l|} 
Pisoniella Arborescens \\
\end{tabular} & $\mathrm{X}$ & & $\mathrm{H}$ \\
\hline Oleaceae & & & \\
\hline Fraxinus Uhdei & $\mathrm{X}$ & & $\mathrm{Ar}$ \\
\hline Onagraceae & & & \\
\hline Lopezia Racemosa & $\mathrm{X}$ & $\mathrm{X}$ & $\mathrm{H}$ \\
\hline Ludwigia Octovalvis & $\mathrm{X}$ & & $\mathrm{H}$ \\
\hline Opiliaceae & & & \\
\hline Agonandra Racemosa & $\mathrm{X}$ & $\mathrm{X}$ & $\mathrm{Ar}$ \\
\hline
\end{tabular}

HERNÁNDEZ-HERNÁNDEZ， Victoria， RAMOS-LÓPEZ， Luis Fernando and COLLI-MULL, Juan Gualberto. Floristic composition in deciduous tropical forest to west of Irapuato, Guanajuato. Journal of Environmental Sciences and Natural Resources. 2019 


\begin{tabular}{|c|c|c|c|}
\hline Orobanchaceae & & & \\
\hline Aphyllon Dugesii & $\mathrm{X}$ & $\mathrm{X}$ & $\mathrm{H}$ \\
\hline Castilleja Tenuiflora & $\mathrm{X}$ & & $\mathrm{H}$ \\
\hline \multicolumn{4}{|l|}{ Oxalidaceae } \\
\hline Oxalis Alpina & $\mathrm{X}$ & $\mathrm{X}$ & $\mathrm{H}$ \\
\hline \multicolumn{4}{|l|}{ Piperaceae } \\
\hline Peperomia Bracteata & $\mathrm{X}$ & $\mathrm{X}$ & $\mathrm{H}$ \\
\hline \multicolumn{4}{|l|}{ Plumbaginaceae } \\
\hline Plumbago Pulchella & $\mathrm{X}$ & $\mathrm{X}$ & $\mathrm{H}$ \\
\hline Plumbago Zeylanica & $\mathrm{X}$ & $\mathrm{X}$ & $\mathrm{H}$ \\
\hline \multicolumn{4}{|l|}{ Polemoniaceae } \\
\hline Bonplandia Geminiflora & $\mathrm{X}$ & $\mathrm{X}$ & $\mathrm{H}$ \\
\hline Loeselia Glandulosa & $\mathrm{X}$ & & $\mathrm{H}$ \\
\hline Loeselia Mexicana & $\mathrm{X}$ & $\mathrm{X}$ & Arb \\
\hline Loeselia Pumila & $\mathrm{X}$ & $\mathrm{X}$ & $\mathrm{H}$ \\
\hline \multicolumn{4}{|l|}{ Polygonaceae } \\
\hline Persicaria Segetum & $\mathrm{X}$ & & $\mathrm{H}$ \\
\hline \multicolumn{4}{|l|}{ Ranunculaceae } \\
\hline Clematis Grossa & $\mathrm{X}$ & & B \\
\hline \multicolumn{4}{|l|}{ Rhamnaceae } \\
\hline Colubrina Triflora & & $\mathrm{X}$ & $\mathrm{Ar}$ \\
\hline \multicolumn{4}{|l|}{ Rubiaceae } \\
\hline Bouvardia Laevis & & $\mathrm{X}$ & Arb \\
\hline Bouvardia Multiflora & $\mathrm{X}$ & $\mathrm{X}$ & Arb \\
\hline Randia Canescens & $\mathrm{X}$ & $\mathrm{X}$ & Arb \\
\hline Sapindaceae & & & \\
\hline Cardiospermum Halicacabum & & $\mathrm{X}$ & $\mathrm{B}$ \\
\hline Serjania Triquetra & $\mathrm{X}$ & $\mathrm{X}$ & $\mathrm{B}$ \\
\hline Saxifragaceae & & & \\
\hline Heuchera Mexicana & $\mathrm{X}$ & & $\mathrm{H}$ \\
\hline Scrophulariaceae & & & \\
\hline Buddleja Sessiliflora & $\mathrm{X}$ & $\mathrm{X}$ & Arb \\
\hline Solanaceae & & & \\
\hline Jaltomata Procumbens & $\mathrm{X}$ & $\mathrm{X}$ & $\mathrm{H}$ \\
\hline Physalis Philadelphica & $\mathrm{X}$ & $\mathrm{X}$ & $\mathrm{H}$ \\
\hline $\begin{array}{l}\text { Solanum Diversifolium Subsp. } \\
\text { Diversifolium }\end{array}$ & $\mathrm{X}$ & $\mathrm{X}$ & Arb \\
\hline Solanum Edmundoi & $\mathrm{X}$ & & $\mathrm{B}$ \\
\hline Solanum Nigrescens & $\mathrm{X}$ & & $\mathrm{B}$ \\
\hline Talinaceae & & & \\
\hline Talinum Paniculatum & $\mathrm{X}$ & $\mathrm{X}$ & $\mathrm{H}$ \\
\hline Verbenaceae & & & \\
\hline Lantana Camara & $\mathrm{X}$ & & Arb \\
\hline Lantana Hirta & $\mathrm{X}$ & $\mathrm{X}$ & Arb \\
\hline Lippia Queretarensis & $\mathrm{X}$ & $\mathrm{X}$ & $\mathrm{H}$ \\
\hline Verbena Carolina & $\mathrm{X}$ & & $\mathrm{H}$ \\
\hline Violaceae & & & \\
\hline Pombalia Attenuata & $\mathrm{X}$ & & $\mathrm{H}$ \\
\hline Monocotyledoneae & & & \\
\hline Asparagaceae & & & \\
\hline Echeandia Flavescens & $\mathrm{X}$ & & $\mathrm{H}$ \\
\hline Milla Biflora & $\mathrm{X}$ & & $\mathrm{H}$ \\
\hline Alstroemeriaceae & & & \\
\hline Bomarea Edulis & $\mathrm{X}$ & & B \\
\hline Bromeliaceae & & & \\
\hline Tillandsia Achyrostachys & $\mathrm{X}$ & & $\mathrm{H}$ \\
\hline Tillandsia Dugesii & $\mathrm{X}$ & & $\mathrm{H}$ \\
\hline Tillandsia Grossispicata & & $\mathrm{X}$ & $\mathrm{H}$ \\
\hline Tillandsia Recurvata & $\mathrm{X}$ & $\mathrm{X}$ & $\mathrm{H}$ \\
\hline Viridantha Atroviridipetala & & $\mathrm{X}$ & $\mathrm{H}$ \\
\hline Commelinaceae & & & \\
\hline Commelina Erecta & & $\mathrm{X}$ & $\mathrm{H}$ \\
\hline Thyrsanthemum Floribundum & $\mathrm{X}$ & $\mathrm{X}$ & $\mathrm{H}$ \\
\hline Tradescantia Crassifolia & $\mathrm{X}$ & $\mathrm{X}$ & $\mathrm{H}$ \\
\hline Tripogandra Amplexicaulis & & $\mathrm{X}$ & $\mathrm{H}$ \\
\hline Tripogandra Purpurascens & $\mathrm{X}$ & & $\mathrm{H}$ \\
\hline Dioscoreaceae & & & \\
\hline Dioscorea Galeottiana & $\mathrm{X}$ & $\mathrm{X}$ & $\mathrm{B}$ \\
\hline Iridaceae & & & \\
\hline Tigridia Vanhouttei & $\mathrm{X}$ & $\mathrm{X}$ & $\mathrm{H}$ \\
\hline Orchidaceae & & & \\
\hline Dichromanthus Cinnabarinus & & $\mathrm{X}$ & $\mathrm{H}$ \\
\hline Govenia Lagenophora & $\mathrm{X}$ & & $\mathrm{H}$ \\
\hline Sacoila Lanceolata & $\mathrm{X}$ & & $\mathrm{H}$ \\
\hline Poaceae & & & \\
\hline Lasiacis Nigra & $\mathrm{X}$ & & $\mathrm{H}$ \\
\hline Melinis Repens & $\mathrm{X}$ & $\mathrm{X}$ & $\mathrm{H}$ \\
\hline Pontederiaceae & & & \\
\hline Heteranthera Peduncularis & $\mathrm{X}$ & & $\mathrm{H}$ \\
\hline
\end{tabular}

